BUILDING EXPERIMENTS 



\title{
BUILDING EXPERIMENTS
}

Testing Social Theory

\author{
David Willer \\ Henry A. Walker
}

Stanford Social Sciences

An imprint of Stanford University Press

Stanford, California 
Stanford University Press

Stanford, California

$\Theta_{2007}$ by the Board of Trustees of the Leland Stanford Junior University.

All rights reserved.

No part of this book may be reproduced or transmitted in any form or by any means, electronic or mechanical, including photocopying and recording, or in any information storage or retrieval system without the prior written permission of Stanford University Press.

Library of Congress Cataloging-in-Publication Data

Willer, David.

Building experiments : testing social theory / David Willer and Henry A. Walker. p. $\mathrm{cm}$.

Includes bibliographical references and index.

ISBN 978-0-8047-5245-9 (cloth : alk. paper) - ISBN 978-0-8047-5246-6 (pbk. :

alk. paper)

1. Sociology -- Methodology. 2. Experimental design. I. Walker, Henry A., 1943II. Title.

HM514.W55 2007

$301.072-\mathrm{dc} 22$

2007001002

Typeset by Newgen-Austin in 10/14 Minion 